\title{
Biodynamic agriculture research progress and priorities
}

\author{
M. Turinek, S. Grobelnik-Mlakar, M. Bavec and F. Bavec* \\ Faculty of Agriculture and Life Sciences, Institute for Organic Farming, University of Maribor, Pivola 10, \\ 2311 Hoče, Slovenia. \\ *Corresponding author: franci.bavec@uni-mb.si
}

\begin{abstract}
Biodynamic (BD) agriculture became the subject of research efforts during the past decades, whereas a part of the scientific community looks at the BD method with skepticism and marks it as dogmatic. Nevertheless, as explored in this review, a fair share of the available peer-reviewed research results of controlled field experiments as well as case studies show effects of BD preparations on yield, soil quality and biodiversity. Moreover, BD preparations express a positive environmental impact in terms of energy use and efficiency. However, the underlying natural science mechanistic principle of BD preparations is still under investigation. In addition, quality determination methods, based on holistic approaches, are increasingly being investigated and recognized. BD farming strives, as manifested in several publications, to positively impact cultural landscape design as well. Summarized data showed that further research is needed and thus encouraged in the field of food quality comparison/determination, food safety, environmental performance (e.g., footprints), and on the effects of BD farming practices on farm animals.
\end{abstract}

Key words: biodynamic, research, basic experiments, case studies, quality assessment, landscape development

\section{Introduction}

Biodynamic (BD) agriculture, as one of the organic (ORG) agricultural farming methods, was proposed by Steiner ${ }^{1}$ and the BD farming method is striving for diversified, resilient and ever-evolving farms, which could provide ecological, economical and physical long-term sustainability for humankind. It encompasses practices of composting, mixed farming systems with use of animal manures, crop rotations, care for animal welfare, looking at the farm as an organism/entity and local distribution systems ${ }^{2}$, all of which contribute toward the protection of the environment, safeguard biodiversity and improve livelihoods of farmers. Nowadays, there are more than 4200 BD farms in 43 countries, the area of which, over $128,000 \mathrm{ha}$, is certified according to Demeter standards ${ }^{3}$. Next to the standards of ORG agriculture, Demeter standards demand the use of BD preparations, keeping of farm animals, use of animal manures, and strongly encourage local production and distribution systems using local breeds and varieties. Stringent processing standards are in place as well ${ }^{3}$. The BD method emphasizes a holistic approach toward farming and became the subject of research efforts during the past decades.
However, to what extent can biodynamics be regarded as a scientific category? This review paper will explore and summarize up-to-date peer-reviewed scientific papers, $\mathrm{PhD}$ theses and include other sources, where additional information is needed to explain the background and modes of action. Basic experiments, case studies, food quality comparisons and landscape design and its development are expected to differentiate between biodynamics and other production systems. Although significant differences were attained with the use of the BD method, the exact mode of action of $\mathrm{BD}$ preparations, which present the greatest difference from the ORG production method, remains unexplained. Published research data will be analyzed and future development will be brought into focus to better understand and explain the BD farming method. Finally, research proposals and future implications are put into the wider perspective.

\section{Basic Experiments}

Besides published results of short-term trials and aimed research $^{4-8}$, several long-term trials have been effected with the inclusion of the BD farming method and/or BD preparations (Table 1), where all $\mathrm{BD}$ preparations, given in Table 2, were used. 
Table 1. The main characteristics of long-term trials, which are based on sound scientific methods and include BD research.

\begin{tabular}{|c|c|c|c|c|c|}
\hline $\begin{array}{l}\text { Country } \\
\text { of trial }\end{array}$ & Trial description & $\begin{array}{l}\text { Duration } \\
\text { of trial }\end{array}$ & $\begin{array}{c}\text { Size of } \\
\text { experimental } \\
\text { plots }\end{array}$ & $\begin{array}{l}\text { Crop rotation } \\
\text { and fertilization }\end{array}$ & References \\
\hline $\begin{array}{l}\text { Therwil, } \\
\text { Switzerland }\end{array}$ & $\begin{array}{l}\text { In the DOK trial biodynamic, } \\
\text { organic, conventional } \\
\text { farmyard manure and } \\
\text { conventional-mineral farming } \\
\text { systems are compared with } \\
\text { control plots }\end{array}$ & $\begin{array}{l}\text { 1978-the } \\
\text { present }\end{array}$ & $10 \mathrm{~m} \times 10 \mathrm{~m}$ & $\begin{array}{l}\text { Crop rotation same in all } \\
\text { systems } \\
2 \text { fertilizing intensities }(0.7 \\
\text { and } 1.4 \text { livestock units) } \\
\text { FYM }^{1} \text {, composted } \mathrm{FYM}^{1} \\
\text { with added } \mathrm{BD}^{3} \\
\text { preparations and } \mathrm{MIN}^{2} \\
\text { are used, depending on } \\
\text { production system }\end{array}$ & $\begin{array}{l}\text { Pfiffner and Mäder }{ }^{19} \text {; } \\
\text { Mäder et al. }{ }^{13} ; \\
\text { Fließbach et al. }^{14}\end{array}$ \\
\hline $\begin{array}{l}\text { Darmstadt, } \\
\text { Germany }\end{array}$ & $\begin{array}{l}\text { With the MIN-ORG trial, } \\
\text { maintained at the Institute for } \\
\text { Biodynamic Research, the } \\
\text { question of mineral versus } \\
\text { organic fertilizers is tackled }\end{array}$ & $\begin{array}{l}\text { 1980-the } \\
\text { present }\end{array}$ & $5 \mathrm{~m} \times 5 \mathrm{~m}$ & $\begin{array}{l}\text { Same crop rotation and } \\
\text { similar soil tillage are } \\
\text { used in all treatments } \\
\text { Nitrogen (N) input levels are } \\
\text { maintained at the same } \\
\text { level, whereas } \mathrm{MIN}^{2}, \\
\mathrm{FYM}^{1} \text { and composted } \\
\mathrm{FYM}^{1} \text { with added BD } \\
\text { preparations are used to } \\
\text { supply } \mathrm{N} \text { to the soil }\end{array}$ & Raupp $^{22}$ \\
\hline $\begin{array}{l}\text { Bonn, } \\
\text { Germany }\end{array}$ & $\begin{array}{l}\text { Effects of traditionally } \\
\text { composted } \mathrm{FYM}^{1} \text { against } \\
\text { two types of } \mathrm{BD}^{3} \text { composted } \\
\mathrm{FYM}^{1} \text { and a control plot } \\
\text { were investigated }\end{array}$ & 1993-2001 & $6 \mathrm{~m} \times 10 \mathrm{~m}$ & $\begin{array}{l}\text { Same 6-year crop rotation } \\
\text { with similar land- } \\
\text { management techniques } \\
\text { was used } \\
\text { FYM }^{1} \text { and composted } \mathrm{FYM}^{1} \\
\text { with added BD } \\
\text { preparations were used } \\
\text { as fertilizers at a rate of } \\
30 \mathrm{tha}^{-1}\end{array}$ & Zaller and Köpke ${ }^{16}$ \\
\hline $\begin{array}{l}\text { Therwil, } \\
\text { Switzerland }\end{array}$ & $\begin{array}{l}\text { Three-factorial experiment } \\
\text { with } \mathrm{BD}^{3} \text { preparations, soil } \\
\text { tillage and fertilization as } \\
\text { investigated factors }\end{array}$ & $\begin{array}{l}2002-\text { the } \\
\text { present }\end{array}$ & $12 \mathrm{~m} \times 12 \mathrm{~m}$ & $\begin{array}{l}\text { Same crop rotation in all } \\
\text { treatments } \\
\mathrm{FYM}^{1} \text { or slurry is applied to } \\
\text { crops at an intensity of } \\
1.4 \text { livestock units }\end{array}$ & Berner et al. ${ }^{50}$ \\
\hline
\end{tabular}

I FYM - farmyard manure.

2 MIN - mineral fertilizers.

$3 \mathrm{BD}$ - biodynamic.

Table 2. Numbers of BD preparations, their main ingredients, mode of use and predicted influence.

\begin{tabular}{llll}
\hline $\begin{array}{l}\text { Number of } \\
\text { preparation }\end{array}$ & Main ingredient ${ }^{1}$ & Use & $\begin{array}{l}\text { Mentioned in } \\
\text { connection with: }\end{array}$ \\
\hline BD 500 & Cow manure & Field spray & Soil biological activity \\
BD 501 & Silica & Field spray & Plant resilience \\
BD 502 & Yarrow flowers (Achillea millefolium L.) & Compost preparation/inoculant & K and S processes \\
BD 503 & Chamomile flowers (Matricaria recutita L.) & Compost preparation/inoculant & Ca and K processes \\
BD 504 & Stinging nettle shoots (Urtica dioica L.) & Compost preparation/inoculant & $\mathrm{N}$ management \\
BD 505 & Oak bark (Quercus robur L.) & Compost preparation/inoculant & Ca processes \\
BD 506 & Dandelion flowers (Taraxacum officinale Web.) & Compost preparation/inoculant & Si management \\
BD 507 & Valerian extract (Valeriana officinalis L.) & Field spray, compost preparation/inoculant & P and warmth processes
\end{tabular}

$I$ The procedure of preparation and fermentation is described in detail by Steiner ${ }^{1}$. $\mathrm{BD}$ preparations are designed to be used together on a farm/farming system. 
Table 3. Yield comparison of some crops under different agricultural production systems.

\begin{tabular}{|c|c|c|c|c|c|c|c|c|c|c|c|c|c|}
\hline \multirow[b]{2}{*}{ Treatments } & \multicolumn{3}{|c|}{ Wheat yield } & \multicolumn{3}{|c|}{ Potato yield } & \multicolumn{3}{|c|}{ Rye yield } & \multicolumn{3}{|c|}{ Grass-clover yield } & \multirow[b]{2}{*}{ Source } \\
\hline & $\mathrm{CON}^{I}$ & $\mathrm{ORG}^{2}$ & $\mathbf{B D}^{3}$ & $\mathrm{CON}^{1}$ & $\mathrm{ORG}^{2}$ & $\mathbf{B D}^{3}$ & $\mathrm{CON}^{I}$ & $\mathrm{ORG}^{2}$ & $\mathbf{B D}^{3}$ & $\operatorname{CON}^{I}$ & $\mathrm{ORG}^{2}$ & $\mathbf{B D}^{3}$ & \\
\hline & 110 & 99 & 100 & 154 & 102 & 100 & $\mathrm{n} / \mathrm{a}$ & $\mathrm{n} / \mathrm{a}$ & $\mathrm{n} / \mathrm{a}$ & 125 & 92 & 100 & Mäder et al. ${ }^{13}$ \\
\hline & $\mathrm{n} / \mathrm{a}$ & 99 & 100 & $\mathrm{n} / \mathrm{a}$ & 101 & 100 & $\mathrm{n} / \mathrm{a}$ & 100 & 100 & $\mathrm{n} / \mathrm{a}$ & 91 & 100 & Zaller and Köpke ${ }^{16}$ \\
\hline & 104 & 99 & 100 & 103 & 94 & 100 & 126 & 94 & 100 & $\mathrm{n} / \mathrm{a}$ & $\mathrm{n} / \mathrm{a}$ & $\mathrm{n} / \mathrm{a}$ & Raupp $^{22}$ \\
\hline & $\mathrm{n} / \mathrm{a}$ & No di & ference & $\mathrm{n} / \mathrm{a}$ & $\mathrm{n} / \mathrm{a}$ & $\mathrm{n} / \mathrm{a}$ & $\mathrm{n} / \mathrm{a}$ & $\mathrm{n} / \mathrm{a}$ & $\mathrm{n} / \mathrm{a}$ & $\mathrm{n} / \mathrm{a}$ & $\mathrm{n} / \mathrm{a}$ & $\mathrm{n} / \mathrm{a}$ & Berner et al. ${ }^{50}$ \\
\hline Average & 107 & 99 & 100 & 128.5 & 97.5 & 100 & 126 & 97 & 100 & 125 & 91.5 & 100 & \\
\hline
\end{tabular}

Yield relative to $\mathrm{BD}=100$.

n/a - no data available.

${ }^{1} \mathrm{CON}$ - conventional or mineral treatments.

2 ORG - organic treatments.

3 BD - biodynamic treatments.

BD preparations (Table 2) are one of the main features of $\mathrm{BD}$ agriculture. The thoughts behind the preparations are unconventional and sometimes difficult to understand ${ }^{2}$ and the up-to-date underlying natural science mechanistic principle of BD preparations is still under investigation, whereas some attempts have been made to explain the mode of action. Effects were first explained as a normalization (normalizing yields under low-yielding conditions) or compensation (BD preparations compensating for lower $\mathrm{N}$ fertilization) effect, where both explanations leave many open questions ${ }^{9}$. A systems response and adaptation model was suggested as a possible explanation, where the effects of $\mathrm{BD}$ preparations do not depend only on their properties and mode of application. Foremost, properties of soils, plants, environmental conditions and how they interact are suggested as factors, which determine the effects of $\mathrm{BD}$ preparations to the greatest extent ${ }^{9}$. Moreover, BD preparations are applied in small quantities of $4-160 \mathrm{~g} \mathrm{ha}^{-1}$, where physical or biological effects seem unlikely ${ }^{2}$. However, bioactive ingredients, such as herbicides, have also been found to have a great influence in small (less than $10 \mathrm{~g} \mathrm{ha}^{-1}$ ) amounts ${ }^{10}$. In addition, BD preparations were also shown to have hormone-like effects ${ }^{11}$. To better understand the mechanisms behind the BD preparations and to determine ongoing processes in plant physiology, further research designed to separate the effects of the preparations from other aspects of BD farming is needed.

\section{Microorganisms at work}

Experimental results show effects of BD preparations not only on yields (Table 3 ), but also on some ongoing processes in compost piles and in the long term in the soil. Carpenter-Boggs et al. ${ }^{5}$ report higher average temperatures ( $3.4^{\circ} \mathrm{C}$ higher compared with the control pile) throughout the active composting period, whereas Zaller $^{8}$ measured no significant differences in the average temperature of $\mathrm{BD}$ and conventional (CON) compost piles. BD-treated compost also contained $65 \%$ more nitrate in the final samples, respired carbon dioxide $\left(\mathrm{CO}_{2}\right)$ at a $10 \%$ lower rate, and had a larger dehydrogenase enzyme activity to $\mathrm{CO}_{2}$ production ratio ${ }^{5}$. Carpenter-Boggs et al. ${ }^{5}$ suggest that $\mathrm{BD}$ preparations caused these effects through their bioactive ingredients or by serving as microbial inoculants. In addition, the microbial population in BD preparations was found to be substantial $^{12}$, where bacteria population ranged from 3.45 to $8.59 \log _{10} \mathrm{~g}^{-1}$. Also a population of fungi was found in the preparations 502 and 506 (5.30 and $4.26 \log _{10} \mathrm{~g}^{-1}$, respectively). Several bacterial and fungal strains showed a potential for suppressing fungal plant pathogens ${ }^{12}$. This could also be the reason for the significant and clear-cut difference in dehydrogenase, protease and phosphatase activities with respect to the farming systems in the DOK (Biodynamic, Organic and Conventional agriculture longterm comparison) trial, where highest values were measured for the BD system ${ }^{13}$. Microbial biomass nitrogen also differed significantly and was highest in the BD system with $59 \%$ more than that in the $\mathrm{CON}$-farmyard manure (FYM) system ${ }^{14}$. Furthermore, the microbial biomass carbon was $35 \%$ higher in the BD system, compared with the CON-FYM system ${ }^{13,15}$. In contrast, Zaller and Köpke ${ }^{16}$ report no differences between treatments in regard to microbial biomass carbon, where untreated FYM and FYM treated with BD preparations were applied (Table 4). In both cases, microbial biomass carbon was significantly higher than on control plots ${ }^{16}$, which leads to the conclusion that FYM had an important effect on the soil microbial biomass build-up. Wada and Toyota ${ }^{17}$ went a step further and discovered that FYM applications add to the stability of soil biological functions, where microbial and fungal populations show resilience and resistance against disinfection. In addition, FYM contributes toward a changed soil nitrogen composition and higher rates of protein amino acids, which bind nitrogen in the soil ${ }^{18}$. However, differences between treatments do not seem to depend solely on amino acid supply from manure. An altered amino acid metabolism in the soil also influences soil amino acid composition and contents. Soils receiving FYM with BD preparations have a lower catabolism/anabolism ratio than soils receiving non-prepared FYM, which results 


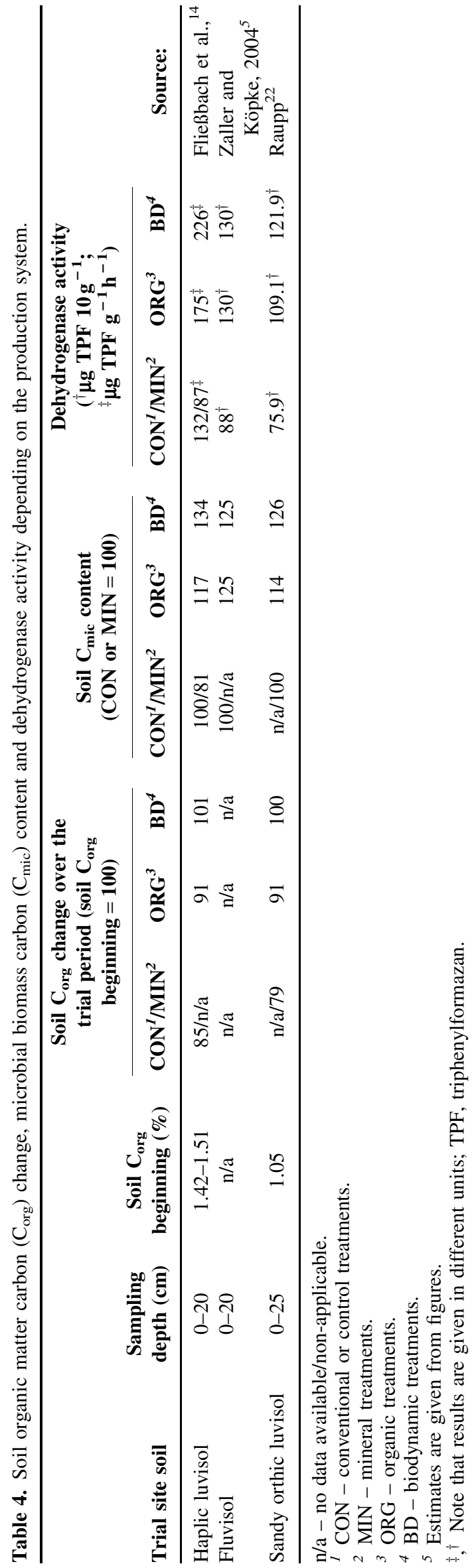

also in a more intensive humification process. The explanation for the influence of $\mathrm{BD}$ preparations on anabolism is yet to be found ${ }^{18}$.

\section{Biodiversity}

In this sense, the effects of ORG and BD farming practices are difficult to separate in terms of macro flora and fauna diversity. In the DOK trial, weed species diversity and arthropod diversity (such as carabids, spiders and staphilinids) were interrelated and were highest in the ORG and $\mathrm{BD}$ treatments over the period of 21 years ${ }^{13}$, which indicates a good site quality. Fließbach et al. ${ }^{14}$ report a less dense, but more diverse weed flora in BD and ORG plots. Furthermore, BD and ORG treatments affect earthworm species composition ${ }^{16}$ and quantity ${ }^{16,19}$. Significant differences between the BD and ORG treatments are reported for earthworm biomass and quantity in one trial ${ }^{19}$ and species composition and biomass in another trial ${ }^{16}$.

However, the BD farming method affects the diversity of soil micro flora and fauna more clearly, where various scientists have come to similar conclusions on the basis of long-term trials. When looking at the complexity and diversity of the microbial food web in soils, the metabolic quotient for $\mathrm{CO}_{2}\left(q \mathrm{CO}_{2}\right)$ indicates the economy of microbial carbon utilization ${ }^{20}$. Higher $q \mathrm{CO}_{2}$ values can indicate young microbial communities with greater energy requirements to maintain itself, whereas lower $q \mathrm{CO}_{2}$ values, which were also found for long-term (more than 8 years) cultivated BD soils, indicate less stressed soils and thus diverse and highly interrelated soil communities ${ }^{11,14-16,18}$. In line with these findings, Carpenter-Boggs et al. ${ }^{6}$ measured higher $q \mathrm{CO}_{2}$ values for soils amended with $\mathrm{BD}$ compost in a 2-year short-term study.

\section{Environmental impacts}

Soil organic matter is an important indicator of the soil organic carbon pool in soils. Increasing the amount of carbon stored in vegetation and soil (also called carbon sequestration) is a preventative measure toward slowing carbon dioxide $\left(\mathrm{CO}_{2}\right)$ build-up in the atmosphere ${ }^{21}$. Soil organic carbon was maintained at the same level for over 21 years and even showed a small gain in the BD system at the DOK trial, whereas the other farming systems investigated all had a net loss of soil organic carbon ${ }^{14}$. Similarly, soil organic matter in the MIN-ORG (mineral versus organic fertilization) trial was maintained at the same level only in the BD, whereas it declined in the FYM and mineral treatments ${ }^{18,22}$. Farm-scale comparisons also show differences between conventional and BD farms, where longterm BD cultivation results in higher soil organic matter levels ${ }^{23,24}$. Next to $\mathrm{CO}_{2}$ and methane, also nitrogen in the form of nitrous oxide plays an important role in greenhouse gas emissions from agricultural land use ${ }^{25}$. With the rising use of supplemental nitrogen added to soils, nitrous oxide emissions also increase and might become a more urgent issue in tackling greenhouse gas emissions from agriculture 
than $\mathrm{CO}_{2}$ is today ${ }^{25}$. When we look at the DOK trial, the ratio between yield levels and nitrogen applied turns out to be highest in the BD and ORG systems, when compared with the conventional and mineral-fertilized systems and ranges from $2: 1,2: 1,1: 1$ to $1: 1.2$, respectively ${ }^{13}$, indicating more efficient use of the nitrogen supplied in BD and ORG systems. Moreover, the BD system contained higher levels of total soil nitrogen on account of soil organic matter and soil microbial biomass when compared with the other systems investigated ${ }^{14}$.

In addition, rising energy prices will eventually intensify interest in the search for farming systems, where energy efficiency would consistently increase and consequently energy consumption per unit will be lower ${ }^{26}$. However, interest is already present, as long-term studies and farm comparisons have been carried out comparing the energy efficiency of different farming systems. Results show better performance of ORG systems ${ }^{26}$, as well as the BD system $^{13}$. As mentioned before, yields are lower in the BD system (compared with the CON-FYM system), but so is the energy consumption: up to $50 \%$ lower mainly due to non-use of external production factors, such as mineral fertilizers and pesticides ${ }^{13}$. This leads to a more energy efficient production in the BD system $(20-56 \%$ better than CON-FYM), in terms of energy consumption per crop unit of dry matter and energy consumption per unit of land $\operatorname{area}^{13}$. Less fossil energy used results in less carbon dioxide being emitted to the atmosphere and thus has a direct impact on global climate change mitigation ${ }^{21}$.

\section{Case Studies of Production Systems}

The first peer-reviewed study directly comparing BD and $\mathrm{CON}$ farms was carried out in New Zealand on $16 \mathrm{farms}^{23}$. BD farming practices for at least 8 years resulted in higher soil organic matter contents, increased quality of soil structure, increased microbial activity and higher numbers of earthworms. BD farms were financially as viable as their CON counterparts.

Droogers and Bouma ${ }^{24}$ compared BD and CON soils on two neighboring farms, where each farming practice has been applied for at least 70 years. They found significant differences in soil organic matter (SOM) content and water availability in favor of BD soils. In addition, soil density, and thus compaction, was lower in BD soils. Initial research provided data for a simulation model, in which BD farming practices expressed higher yield potential, long-term stability and sustainability than CON soils.

Several comparisons between BD and CON farms have been effected in Australia, where the main focus was on phosphorus $(\mathrm{P})$ availability in relation to arbuscular mycorrhizal fungi, since $\mathrm{P}$ is a limiting nutrient in Australian $\operatorname{soils}^{27}$. According to Ryan et $\mathrm{al}^{28}$, there is a strong negative correlation between the levels of $\mathrm{P}$ (soil extractable and in pasture shoots) and arbuscular mycorrhizal fungi colonization in white clover and rye grass, where BD plants and soils contain less extractable $\mathrm{P}$, but have higher levels of arbuscular mycorrhizal fungi colonization. Also, a steady decline of arbuscular mycorrhizal fungi in two out of three CON farms was observed. However, it is suggested that higher arbuscular mycorrhizal fungi colonization cannot compensate for the lower levels of soil extractable $\mathrm{P}$ in the final yields of BD systems. It is discussed that nutrient mobilization from soil minerals is not the only benefit of arbuscular mycorrhizal fungi. Frey-Klett et al. ${ }^{29}$ report that fixation of atmospheric nitrogen and protection of plants against root pathogens are also among the myriad benefits of arbuscular mycorrhizal fungi and mycorrhiza helper bacteria. Raupp ${ }^{22}$ also reports a higher density of roots on plots treated with BD preparations. Mycorrhiza helper bacteria could be the possible reason for this effect, as they have been proved to stimulate lateral root formation and thus increase potential root-mycorrhiza interaction points ${ }^{29}$.

Burkitt et al..$^{30}$ compared ten BD and CON dairy farms for 4 years in northern Victoria and New South Wales. In some points, findings are comparable with results of longterm systems trials done in Europe, where soil $\mathrm{P}$ has a negative balance. The $\mathrm{N}$ and $\mathrm{K}$ balance, however, is reported to be non-significantly different between $\mathrm{BD}$ and $\mathrm{CON}$ farms. Soil organic carbon and soil microbial biomass are also reported to be equal between the farming systems. In addition, earthworm biomass was greater in the CON system on account of one earthworm species, where no information was given on the number of earthworms. Burkitt et al. ${ }^{31}$ also report lower milk yields on BD farms on a per hectare and per cow basis. A significantly greater number of chemical treatments per cow were used on CON farms. However, this did not result in reduced parasitic infection, for infection levels were similar on both farm types. In addition, somatic cell count was higher on farms under BD management, where, in turn, significantly fewer chemical treatments were used. Information on incidences of clinical mastitis and longevity of animals, however, is not provided. Burkitt et al. ${ }^{31}$ suggested the use of certified inputs on BD farms to increase milk fat, protein and production levels, but did not give further details. This was the only published study found that dealt with farm animals and BD farming practices; thus a serious lack of research projects/results is found and research in this area is strongly encouraged.

The difference between Australian BD farms reported in studies and other BD field trial comparison studies and farm comparisons is, however, that in Australia only preparation BD 500 was applied 1-2 times each year ${ }^{27}$. Also Nguyen and Haynes ${ }^{32}$ report only preparation BD 500 being used on a BD farm in New Zealand. As discussed in the professional literature, however, the preparations were designed to be used together and only as such can they have the desired effectiveness. In addition, because of all-year grazing farming systems, Ryan and $\mathrm{Ash}^{27}$ report no additional organic fertilizers added to soils for over 17 years. Nguyen and Haynes $^{32}$ also report no organic or inorganic fertilizers being used on $\mathrm{BD}$ soils and as a consequence also lower yields in a 4-year crop rotation (without pastures). In 
addition, results of previous studies were confirmed, which indicate BD farming systems as more energy efficient (both in terms of crops and animals) on a per hectare basis but at the same time also more labor intensive than conventional farms ${ }^{32}$.

$\mathrm{BD}$ wine grape production is also increasingly attracting attention, as some of the world's prestigious wine producers have started to use BD practices in the past decade ${ }^{7}$. Research followed suit and experimental results suggest that BD practices have an effect on wine grape canopy and chemistry, whereas no significant effects on soil fertility parameters were shown in a 6-year on-farm comparison trial between ORG and BD practices in an organic vineyard in California ${ }^{7}$. Probst et al. ${ }^{33}$, however, measured significant differences in soil fertility between CON and BD soils on farms with a long history of BD (since 1981) and CON cultivation. Results are in accordance with the findings stated in Table 4. More research is needed to make conclusive statements on quality performance and a long-term systems comparison trial in wine grape production would be of great scientific and practical value.

\section{Quality Assessment}

Biocrystallization and the capillary dynomalysis (or Steigbild) method are two so-called picture forming or holistic methods to assess food quality and origin. Although originating in the $1930 \mathrm{~s}$, in recent years they have gained more attention as innovative quality concepts ${ }^{34}$, not only in connection with BD, but also with ORG agriculture. The methods have been developed from the viewpoint that living organisms do not just exist as substances, but have structuring and organizing properties (i.e., one can know the exact composition and quantity of elements an apple has, but still cannot 'produce' an apple by mixing those sub-stances). These properties control the form and function of an organism ${ }^{35}$. At first, soluble extracts of the desired food product are prepared according to the defined working standards of each method, which have been up-todate validated and tested on several samples originating from controlled field system comparisons ${ }^{34}$. Furthermore, a Triangle network of laboratories dealing with bio-crystallization (University of Kassel, Louis Bolk Instituut and Biodynamic Research Association, Denmark) was established, whose goal is to develop uniform ISO standards for the evaluation of biocrystallograms and dynomalysis pictures $^{36}$. Next to the introduction of computer image analysis $^{37}$, a modified method of panel evaluation of obtained images, using a defined set of ten criteria, was tested and successfully applied ${ }^{34}$. With the use of these methods, however up-to-date, one is able to discriminate only products originating from controlled field trials with different production methods, and thus create reference lines. Plants grown in different climatic and environmental conditions express different qualitative parameters and therefore one is unable to make direct comparisons and conclusive statements on the quality of such plants, which is also true for sensory evaluation methods. Recent promising results from renowned institutions and an increasing number of dissertations in the past years could spur even more interest and acceptance of picture-forming quality determination methods.

\section{Landscape Development in Relation to Biodynamics}

The idea of a farm organism or farm individuality is one of the core principles of BD agriculture ${ }^{1}$. Usually it indicates that farm management should minimize nutrient and energy inputs in order to make the farm self-supporting and autonomous $^{38}$, which is true also for ORG farms. But it also encompasses a broader idea of the farm placement in its surroundings, the involvement of the people working on the farm, a balance between the sub-systems or 'organs' of the farm (arable crops, pastures, livestock, horticulture, etc.) and the elements of nature, such as forests, heaths, moors and watercourses ${ }^{38}$. In addition, $\mathrm{Ho}$ and Ulanowicz ${ }^{39}$ provide supportive arguments for an organisms point of view upon sustainable systems, based on thermodynamics. If we extend this point of view to a greater scale, a farm also plays an important role in landscape design and development. For this reason, a bottom-up, present situation improvement approach toward landscape design on farms has been developed, where it is aimed to develop naturecompliant agricultural systems, starting with the acceptance of the natural conditions and developing them according to the needs of the society ${ }^{38,40}$. The Goethean-phenomenological approach has, next to CON methods and solutions, an integral part in this method of landscape assessment, design and development ${ }^{41}$. In conjunction with the abovementioned methods this bottom-up approach resembles participatory action research, where researchers are not merely observers of the system, but actively take part in the process of shaping $\mathrm{it}^{42}$. Moreover, it is argued that sustainable and ecologically sound management of the landscape cannot be achieved only by top-down planning and regulations, but rather with bottom-up, individual and participatory landscape development ${ }^{40}$. Indeed, solutions to problems of one farm do not necessarily solve the same type of problem on another farm and tailor-made solutions should be applied, where demanded ${ }^{38}$. Encompassing a broader set of goals than just landscape design, Helmfried et al. $^{43}$ used participatory action research methods to research and shape local, sustainable and environmentally friendly food systems. Linking both approaches with a goal of improving agricultural and natural systems is a promising future perspective.

\section{Conclusion}

Many questions on BD farming practices have been addressed in the past decades and results have been published in more than 30 peer-reviewed scientific papers. We 
have a better understanding of the effects of BD farming on soil physical, chemical and biological properties, crop growth, yield, processes in soils, etc. BD farming practices are also gaining importance in the face of increasing climate change, energy scarcity and population growth, where they indicate a more resilient, diverse and efficient system. In this sense, BD farming presents a viable farming method, which is worthy of study in more detail on its own account. But what are the priorities in moving forward? Is getting a deeper understanding of the exact mode of action of BD preparations one of them? Until now no fully satisfactory natural science mechanistic principles explanation has been provided. However, the systems response and adaptation model $^{9}$ does give a partial, but promising, explanation. But still, does this lack of clarity make the BD method unscientific? There is also no satisfactory explanation on the pathways and mechanisms of soil organic matter equilibrium establishment in soils ${ }^{44}$, but the topic is still considered to be of high research interest to scientists. So in order to better understand the role and effects of BD preparations, some methods such as photosynthesis measurements and isotope marking could also be taken into consideration. It is important to search for inspiration in the 'Agricultural course', ${ }^{1}$ but also make a step ahead and develop new ideas, research current challenges we are faced with ${ }^{45}$ and build new, yet undiscovered perspectives of BD agriculture, while taking into account over 80 years of experience ${ }^{46}$ with the BD method.

What about energy efficiency on a wider scale (production to consumption)? Does it make a difference if the preparations are made on-farm or bought from a distant location? Does this affect the effectiveness of the preparations? Must the making of the preparations with the use of animal organs stay as given by Steiner ${ }^{1}$ ? Or do we need to move forward, explore new possibilities and develop an understanding of the reasons behind given procedures? This is especially an important issue in the face of recent stringent EU hygiene and sanitary regulations ${ }^{47}$, which were put in place because of animal diseases that originated in industrial farming. What about research on farm animals? Moreover, is there a difference between BDprepared compost of animal and plant origin? How does this affect soil fertility and health? And after all, do we need to make more production systems comparison trials? If yes, how well defined are the systems to be compared? And what are the areas of interest to compare? Food quality is certainly a still highly discussed and debated area, which would deserve more attention on this account.

A working group of researchers and professionals, who have gathered in an active process to exchange thoughts, experiences and research results ${ }^{48}$, is certainly a signpost into the future. Also a web portal on biodynamic research ${ }^{49}$, which was recently put into practical existence, could facilitate the exchange of ideas, thoughts and results. A worldwide network of farmers, researchers, advisors, teachers and others interested in BD farming could contribute toward naming and addressing questions from everyday practice in order to make important steps toward a more sustainable, healthy, prosperous and secure future.

\section{Reviewer's Response}

At the Editor's suggestion we are including a reviewer's perspective in order to broaden the understanding of the subject matter:

'My personal perspective is that the authors do not need to ask whether BD can be regarded as a scientific category or even point out that part of the scientific community looks at it with skepticism and marks it as dogmatic. There are over 4200 farms around the world that are certified as BD so it is clearly worthy of study. There are also many research studies and publications identifying the benefits of organic farming and the ability to maintain yields and improve soil health with organic farming methods. To my knowledge BD includes all the key components of ORG so what is true for ORG is true for BD.'

Acknowledgements. We thank both anonymous reviewers for their constructive and useful criticism that has improved this paper, especially reviewer no. 2 for motivating us to extend the 'Conclusions' section. This review is the initial part of a future $\mathrm{PhD}$ thesis, based on two research projects (L4-957-0482-06 and J4-9532-0482-07) that are funded by the Ministry of Higher Education, Science and Technology of Slovenia. We acknowledge the Ministry of Higher Education, Science and Technology of Slovenia for financial support.

\section{References}

1 Steiner, R. 1924. Geisteswissenschaftliche Grundlagen zum Gedeihen der Landwirtschaft. Rudolf Steiner Verlag, Dornach.

2 Reganold, J.P. 1995. Soil quality and profitability of biodynamic and conventional farming systems: A review. American Journal of Alternative Agriculture 10:36-45.

3 Demeter International e.V. 2008. Demeter International e.V. A World-wide Network. http://www.demeter.net/ (verified 10 December 2008).

4 Ryan, M. and Ash, J. 1999. Effects of phosphorus and nitrogen on growth of pasture plants and VAM fungi in SE Australian soils with contrasting fertiliser histories (conventional and biodynamic). Agriculture, Ecosystems and Environment 73: 51-62.

5 Carpenter-Boggs, L., Reganold, J.P., and Kennedy, A.C. 2000. Effects of biodynamic preparations on compost development. Biological Agriculture and Horticulture 17:313-328.

6 Carpenter-Boggs, L., Kennedy, A.C., and Reganold, J.P. 2000. Organic and biodynamic management: effects on soil biology. Soil Science Society of America Journal 64:1651-1659.

7 Reeve, J.R., Carpenter-Boggs, L., Reganold, J.P., York, A.L., McGourty, G., and McCloskey, L.P. 2005. Soil and winegrape quality in biodynamically and organically managed vineyards. American Journal of Enology and Viticulture 56:367-376.

8 Zaller, J.G. 2007. Seed germination of the weed Rumex obtusifolius after on-farm conventional, biodynamic and vermicomposting of cattle manure. Annals of Applied Biology 151:245-249. 
9 Raupp, J. and König, U.J. 1996. Biodynamic preparations cause opposite yield effects depending upon yield levels. Biological Agriculture and Horticulture 13:175-188.

10 Zimdahl, R. 1999. Fundamentals of Weed Science. Academic Press, San Diego, CA.

11 Goldstein, W., Barber, W., Carpenter-Boggs, L., Daloren, D., and Koopmans, C. 2004. Comparisons of conventional, organic and biodynamic methods. Michael Fields Agricultural Institute. Available at Web site http://www.michaelfieldsaginst. org/education/comparison.pdf (verified 30 June 2008).

12 Rupela, O.P., Gopalakrishnan, S., Krajewski, M., and Sriveni, M. 2003. A novel method for the identification and enumeration of microorganisms with potential for suppressing fungal pathogens. Biology and Fertility of Soils 39:131-134.

13 Mäder, P., Fließbach, A., Dubois, D., Gunst, L., Fried, P., and Niggli, U. 2002. Soil fertility and biodiversity in organic farming. Science 296:1694-1697.

14 Fließbach, A., Oberholzer, H.R., Gunst, L., and Mäder, P. 2007. Soil organic matter and biological soil quality indicators after 21 years of organic and conventional farming. Agriculture, Ecosystems and Environment 118:273-284.

15 Oehl, F., Frossard, E., Fließbach, A., Dubois, D., and Oberson, A. 2004. Basal organic phosphorus mineralization in soils under different farming systems. Soil Biology and Biochemistry 36:667-675.

16 Zaller, J.G. and Köpke, U. 2004. Effects of traditional and biodynamic farmyard manure amendment on yields, soil chemical, biochemical and biological properties in a long-term field experiment. Biology and Fertility of Soils 40:222-229.

17 Wada, S. and Toyota, K. 2007. Repeated applications of farmyard manure enhance resistance and resilience of soil biological functions against soil disinfection. Biology and Fertility of Soils 43:349-356.

18 Scheller, E. and Raupp, J. 2005. Amino acid and soil organic matter content of topsoil in a long term trial with farmyard manure and mineral fertilizers. Biological Agriculture and Horticulture 22:379-397.

19 Pfiffner, L. and Mäder, P. 1997. Effects of biodynamic, organic and conventional production systems on earthworm populations. Biological Agriculture and Horticulture 15:3-10.

20 Anderson, T.H. and Domsch, K.H. 1993. The metabolic quotient for $\mathrm{CO}_{2}\left(q \mathrm{CO}_{2}\right)$ as a specific activity parameter to assess the effects of environmental conditions, such as $\mathrm{pH}$, on the microbial biomass of forest soils. Soil Biology and Biochemistry 25:393-395.

21 Janzen, H.H. 2004. Carbon cycling in earth systems - a soil science perspective. Agriculture, Ecosystems and Environment 104:399-417.

22 Raupp, J. 2001. Forschungsthemen und Ergebnisse eines Langzeitdüngungsversuchs in zwei Jahrzehnten; ein Beitrag zur Bewertung von pflanzenbaulichen Langzeitversuchen. Berichte über Landwirtschaft 79:71-93.

23 Reganold, J.P., Palmer, A.S., Lockhart, J.C., and MacGregor, A.N. 1993. Soil quality and financial performance of biodynamic and conventional farms in New Zealand. Science 260:344-349.

24 Droogers, P. and Bouma, J. 1996. Biodynamic vs. conventional farming effects on soil structure expressed by simulated potential productivity. Soil Science Society of America Journal 60:1552-1558.

25 Janzen, H.H. 2006. Greenhouse gases as clues to permanence of farmlands. Conservation Biology 21:668-674.
26 Pimentel, D., Herperly, P., Hanson, J., Douds, D., and Seidel, R. 2005. Environmental, energetic, and economic comparisons of organic and conventional farming systems. BioScience 55: 573-582.

27 Ryan, M. and Ash, J. 1999. Effects of phosphorus and nitrogen on growth of pasture plants and VAM fungi in SE Australian soils with contrasting fertiliser histories (conventional and biodynamic). Agriculture, Ecosystems and Environment 73: 51-62.

28 Ryan, M.H., Small, D.R., and Ash, J.E. 2000. Phosphorus controls the level of colonisation by arbuscular mycorrhizal fungi in conventional and biodynamic irrigated daily pastures. Australian Journal of Experimental Agriculture 40:663-670.

29 Frey-Klett, P., Garbaye, J., and Tarkka, M. 2007. The mycorrhiza helper bacteria revisited. New Phytologist 176:22-36.

30 Burkitt, L.L., Small, D.R., McDonald, J.W., Wales, W.J., and Jenkin, M.L. 2007. Comparing irrigated biodynamic and conventionally managed dairy farms. 1. Soil and pasture properties. Australian Journal of Experimental Agriculture 47:479-488.

31 Burkitt, L.L., Wales, W.J., McDonald, J.W., Small, D.R., and Jenkin, M.L. 2007. Comparing irrigated biodynamic and conventionally managed dairy farms. 2. Milk production and composition and animal health. Australian Journal of Experimental Agriculture 47:489-494.

32 Nguyen, M.L. and Haynes, R.J. 1995. Energy and labour efficiency for three pairs of conventional and alternative mixed cropping (pasture-arable) farms in Canterbury, New Zealand. Agriculture, Ecosystems and Environment 52:163172.

33 Probst, B., Schüler, C., and Joergensen, R.G. 2008. Vineyard soils under organic and conventional management - microbial biomass and activity indices and their relation to soil chemical properties. Biology and Fertility of Soils 44:443-450.

34 Kahl, B.J. 2006. Entwicklung, in-house Validierung und Anwendung des ganzheitlichen Verfahrens Biokristallisation für die Unterscheidung von Weizen-, Möhren- und Apfelproben aus unterschiedlichem Anbau und Verarbeitungsschritten. Habilitationsschrift. University of Kassel, Witzenhausen, Germany.

35 Meelursarn, A. 2006. Statistical evaluation of texture analysis from the biocrystallization method: Effect of image parameters to differentiate samples from different farming systems. PhD thesis. University of Kassel, Witzenhausen.

36 Andersen, J.O., Huber, M., Kahl, J., Busscher, N., and MeierPloeger, A. 2003. A concentration matrix procedure for determining optimal combinations of concentrations in biocrystallization. Elemente der Naturwissenschaft 79:97-114.

37 Andersen, J.O., Henriksen, C.B., Laursen, J., and Nielsen, A.A. 1998. Computerised image analysis of biocrystallograms originating from agricultural products. Computers and Electronics in Agriculture 22:51-69.

38 Vereijken, J.F.H.M., van Gelder, T., and Baars, T. 1997. Nature and landscape development on organic farms. Agriculture, Ecosystems and Environment 63:201-220.

39 Ho, M.W. and Ulanowicz, R. 2005. Sustainable systems as organisms? BioSystems 82:39-51.

40 Beismann, M. 1997. Landscaping on a farm in northern Germany, a case study of conceptual and social fundaments for the development of an ecologically sound agro-landscape. Agriculture, Ecosystems and Environment 63:173-184. 
41 Colquhoun, M. 1997. An exploration into the use of Goethean science as a methodology for landscape assessment: the Pishwanton Project. Agriculture, Ecosystems and Environment 63:145-157.

42 Greenwood, D.J., Whyte, W.F., and Harkavy, I. 1993. Participatory action research as a process and as a goal. Human Relations 46:175-192.

43 Helmfried, H., Haden, A., and Ljung, M. 2008. The role of action research (AR) in environmental research: learning from a local organic food and farming research project. Systemic Practice and Action Research 21:105-131.

44 Stevenson, F.J. 1994. Humus Chemistry: Genesis, Composition, Reactions. Wiley Interscience, New York.

45 Turinek, M., Grobelnik-Mlakar, S., Bavec, M., and Bavec, F. 2008. Biodynamic agriculture from past to present. Agricultura 6:1-4.
46 Koepf, H., Schaumann, W., and Haccius, M. 1996. Biologisch-dynamische Landwirtschaft. Ulmer Verlag, Stuttgart.

47 Regulation (EC) No. 1774/2002 of the European Parliament and of the Council. Available at Web site http://eur-lex. europa.eu/LexUriServ/site/en/consleg/2002/R/02002R177420060401-en.pdf (verified 10 December 2008).

48 Hurter, M. (ed.) 2007. Zur Vertiefung der biologisch-dynamischen Landwirtschaft. Verlag am Goetheanum, Dornach.

49 Biodynamic-Research-Team. 2008. Biodynamic-Research.net - Information and Communication Network for Research on Biodynamic Agriculture. Available at Web site http://www. biodynamic-research.net/ (verified 10 December 2008).

50 Berner, A., Hildermann, I., Fließbach, A., Pfiffner, L., Niggli, U., and Mäder, P. 2008. Crop yield and soil fertility response to reduced tillage under organic management. Soil Tillage Research 101:89-96. 